Metallophysics and Advanced Technologies

Металофіз. новітні технол.

Metallofiz. Noveishie Tekhnol.

2019 , vol. 41 , No. 12 , pp. $1587-1597$

https://doi.org/10.15407/mfint.41.12.1587

Reprints available directly from the publisher
(C) 2019 G. V. Kurdyumov Institute for Metal Physics, National Academy of Sciences of Ukraine Published by license under the G. V. Kurdyumov Institute for Metal PhysicsN.A.S. of Ukraine Publishers imprint. Printed in Ukraine.

PACS numbers: 68.47.De, 73.20.Mf, 78.30.-j, 79.20.Ds, 79.20.Eb, 81.16.Rf

\title{
Formation Conditions and Morphology of Nanoscale Features on the Surfaces of Metals and Alloys under Femtosecond Laser Treatment
}

\author{
I. M. Dmitruk, N. I. Berezovska, O. A. Yeshchenko, O. P. Stanovyi,
} A. M. Dmytruk*, and I. V. Blonskyi*

Taras Shevchenko National University of Kyiv, 60 Volodymyrska Str. UA-01033 Kyiv, Ukraine

"Institute of Physics, N.A.S. of Ukraine, 46 Nauky Ave.,

UA-03028 Kyiv, Ukraine

Surface texturing of metals and alloys with Ti: Sapphire femtosecond laser has been carried out in air. The peculiarities of surface patterns formed on the surface of noble metals (silver, gold, copper), refractory metal (tungsten) and metal-semiconductor alloy under ultrashort laser pulses have been studied by means of the surface morphology analysis. The influence of the laser ablation process on the formation of nanoscale features on the laser treated surfaces has been discussed. In the experiments, the low fluence multi-pulse regime near the ablation threshold for studied materials has been realized. The average sizes of nanoscale features formed under ultrashort laser processing on the surface structures have been determined for silver, gold, copper and tungsten. Observed enhancement of Raman signal for some vibrations of Methylene Blue dye adsorbed on laser-induced Ag surface structures demonstrates the possibility of an application of the laser-textured substrates as surface enhanced Raman scattering (SERS) substrates used for biosensing.

Key words: laser-induced periodic surface structure, nanoscale feature, ablation, surface plasmon, Surface-enhanced Raman scattering, metal.

Corresponding author: Nataliya Ivanivna Berezovska

E-mail: nberez88@gmail.com

Citation: I. M. Dmitruk, N. I. Berezovska, O. A. Yeshchenko, O. P. Stanovyi, A. M. Dmytruk, and I. V. Blonskyi, Formation Conditions and Morphology of Nanoscale Features on the Surfaces of Metals and Alloys under Femtosecond Laser Treatment, Metallofiz. Noveishie Tekhnol., 41, No. 12: 1587-1597 (2019), DOI: $10.15407 /$ mfint.41.12.1587. 
Текстурування поверхні металів та сплавів за допомогою фемтосекундного Ті-сапфірового лазера здійснювалося у повітрі. За допомогою аналізу морфології поверхні вивчено особливості поверхневих структур, що утворюються на поверхні благородних металів (срібло, золото, мідь), тугоплавких металів (вольфрам) та метал-напівпровідникових сплавів під дією ультракоротких лазерних імпульсів. Обговорено вплив лазерної абляції на формування нанорозмірних особливостей на оброблених лазером поверхнях. В експериментах реалізовано багатоімпульсний режим з низькою густиною потужності біля порогу абляції для досліджуваних матеріалів. Для срібла, золота, міді та вольфраму визначено середні розміри нанорозмірних елементів, сформованих на періодичних поверхневих структурах при лазерній обробці за допомогою ультракоротких лазерних імпульсів. Підсилення сигналу комбінаційного розсіяння світла, що спостерігалось для деяких коливань барвника «Метиленовий синій», адсорбованого на срібних лазерно-індукованих поверхневих структурах, демонструє можливість застосування лазерно-текстурованих підкладок як підкладок для поверхнево-підсиленого комбінаційного розсіяння світла (SERS), що використовують для біосенсорів.

Ключові слова: лазерно-індукована поверхнева структура, нанорозмірна особливість, лазерна абляція, поверхневий плазмон, поверхневопідсилена спектроскопія комбінаційного розсіяння світла, метал.

Текстурирование поверхности металлов и сплавов с помощью фемтосекундного Ті-сапфирового лазера осуществлялось в воздухе. С помощью анализа морфологии поверхности изучены особенности поверхностных структур, образующихся на поверхности благородных металлов (серебро, золото, медь), тугоплавких металлов (вольфрам) и металл-полупроводниковых сплавов под действием ультракоротких лазерных импульсов. Обсуждено влияние лазерной абляции на формирование наноразмерных особенностей на обработанных лазером поверхностях. В экспериментах реализован многоимпульсный режим с низкой плотностью мощности у порога абляции для исследуемых материалов. Для серебра, золота, меди и вольфрама определены средние размеры наноразмерных элементов, сформированных на периодических поверхностных структурах при лазерной обработке с помощью ультракоротких лазерных импульсов. Усиление сигнала комбинационного рассеяния света, наблюдаемое для некоторых колебаний красителя «Метиленовый синий», адсорбированного на серебряных лазерно-индуцированных поверхностных структурах, демонстрирует возможность применения лазерно-текстурированных подложек для поверхностно-усиленного комбинационного рассеяния света (SERS), используемых для биосенсоров.

Ключевые слова: лазерно-индуцированная поверхностная структура, наноразмерная особенность, лазерная абляция, поверхностный плазмон, поверхностно-усиленная спектроскопия комбинационного рассеяния света, металл.

(Received August 2, 2019) 


\section{INTRODUCTION}

Nowadays the surface texturing of the materials of different types is considered as a perspective way to achieve various application purposes. Along with chemical and electrochemical etching methods, the laser surface processing can produce desirable patterns on the material surfaces. The ultrashort pulse laser processing of the materials provides modified surfaces perspective for various applications in physics, chemistry, materials science and engineering. The laser parameters such as wavelength, pulse duration, energy density, as well as the material properties, namely the characteristic times and thermophysical properties of substances, have the crucial role in the laser beam interaction with various materials. Moreover, along with the surface and bulk structure transformation the ultrashort pulse laser treatment induces surface diffusion, oxidation, ablation and deposition processes. The ablation products are adverse for some technology processes such as micromachining, cutting, etc. [1, 2]. It should be noted that ultrashort laser irradiation ensures high quality and precision of surface machining compared to the lasers with nanosecond or longer pulse duration $[3,4]$.

Nevertheless, the disadvantages caused by the ablation process could be applied to certain purposes. One of the promising applications is the usage of laser treated surfaces as the substrates for the surface enhanced Raman scattering (SERS) spectroscopy. SERS method is actively used for biosensing. Numerous papers have elucidated the development of efficient SERS substrates, in particular based on plasmonic nanostructures [5-8]. High-quality SERS substrates have to provide uniform gain factor that could be adjusted by the corresponding surface morphology of the substrates.

In present study, we describe the morphology of the surfaces structured with laser pulses of femtosecond duration, emphasize the peculiarities of nano-sized features on the surface of formed quasi-periodic structures and demonstrate the perspective of such features for SERS applications.

\section{EXPERIMENTAL/THEORETICAL DETAILS}

Micro- and nanostructuring of surfaces of materials under study have been achieved by the irradiation of the samples initial surfaces with a femtosecond laser. A coherent Ti-sapphire laser system used in our experiments consists of Mira-900F femtosecond oscillator with LegendHE chirped pulse amplifier. The main characteristics of the laser beam have been the following: central wavelength of $800 \mathrm{~nm}$, pulse duration of 130-150 fs, pulse energy about $0.8-1 \mathrm{~mJ}$, a pulse repetition rate of 1 $\mathrm{kHz}$. Lenses with the focal length of 100 or $150 \mathrm{~mm}$ are used for the 
beam focusing onto the surface of the sample which was fixed to the holder of a translation stage. The set of the defined values of the irradiation power density are ensured by changing the distance from the lens focus to the sample surface. An average power density at the sample surface is of the order of $10^{12} \mathrm{~W} / \mathrm{cm}^{2}$. The scanning beam mode regime has been realized at a speed range of $0.1-30 \mathrm{~mm} / \mathrm{s}$ for different materials. Typically scanning was performed in horizontal lines with vertical shift equal to the diameter of the beam on the surface. In most cases, the horizontally polarized laser beam is incident normally onto the sample surface. This polarization direction could be changed with the $\lambda / 2$ plate. All laser treatment procedures have been carried out in air.

The surface morphology has been examined using the scanning electron microscopes TESCAN VEGA 3 (Tescan), JSM-35-C (JEOL), atomic force microscope NTEGRA Prima (NT-MDT).

The Raman spectra of Stokes scattering have been obtained under an excitation of a cw Ar ion laser with the wavelength of $476.5 \mathrm{~nm}$ (power $50.0 \mathrm{~mW}$ ) at the 45 -degree incidence angle using a double grating spectrometer DFS-24 (LOMO). The laser beam has been focused at the sample surface with a cylindrical lens that reduces laser power density, and the irradiation distributes over the surface area of $0.2 \times 3 \mathrm{~mm}^{2}$.

We have studied the samples of pure metals $(\mathrm{Ag}, \mathrm{Au}, \mathrm{Cu}$, and $\mathrm{W})$ and aluminium alloy with $20 \%$ silicon.

\section{RESULTS AND DISCUSSION}

The surfaces of various types of materials treated with femtosecond laser pulses often reveal quasi-periodic structures which are parallel sub-micron ripples so-called laser-induced periodic surface structures (LIPSS). Typically, LIPSS period is about 1.5 times smaller than laser wavelength. This ratio can be attributed to the shape of dispersion curve of surface plasmon polariton (SPP) propagating on the surface of metal. And it can be considered as a proof of the best known mechanism of LIPSS formation as a result of interference of incident laser beam and SPP excited on the surface roughness.

Moreover, sometimes besides sub-micron periodic structures porous structures and nanoscale features are observed depending on the laser processing conditions. We have examined the formation of nanofeatures on the surface of ripples under the femtosecond laser pulses irradiation that is to the great extend caused by the ablation processes. The distinctive feature of ablation process under the ultrashort laser pulse irradiation is its non-thermal character. It is co-called process of cold ablation characterized with relatively small amount of molten material. The ablation process is considerably conditioned by an energy density threshold or ablation threshold, above which substantial modifications of the material surface begin to occur. The ablation threshold 
strongly depends on the material thermal properties, parameters of electron-phonon interaction in material and the laser operating parameters, in particular laser wavelength, pulse duration, number of pulses and atmosphere of the laser processing [9]. In literature two different ablation regimes are usually differentiated-the lower fluence regime when the ablation rate is low and less quantity of ablated particles is observed at the ablated surface, and the higher fluence regime with the increased ablation rate which is resulted in higher surface damages after laser processing [10]. The two-temperature model (TTM) describing the mechanism of the laser energy absorption by the materials electron subsystem and subsequent transfer of the thermal energy to the lattice subsystem has been firstly proposed in the early 80's [11, 12]. Further hybrid theoretical models combining TTM, molecular dynamics and hydrodynamic models improved the reliability of the numerical calculations [13].

In our experiments the lower fluence multi-pulse regime near the ablation threshold for materials under study has been realized. In some experiments the ablation threshold may be exceeded. The morphology analysis of processed surfaces has been conducted on the basis of analysis of SEM and AFM images.

At Figures 1-4 the SEM and AFM images of different nanoscale features on the laser treated surfaces of noble metals-silver, gold, copper

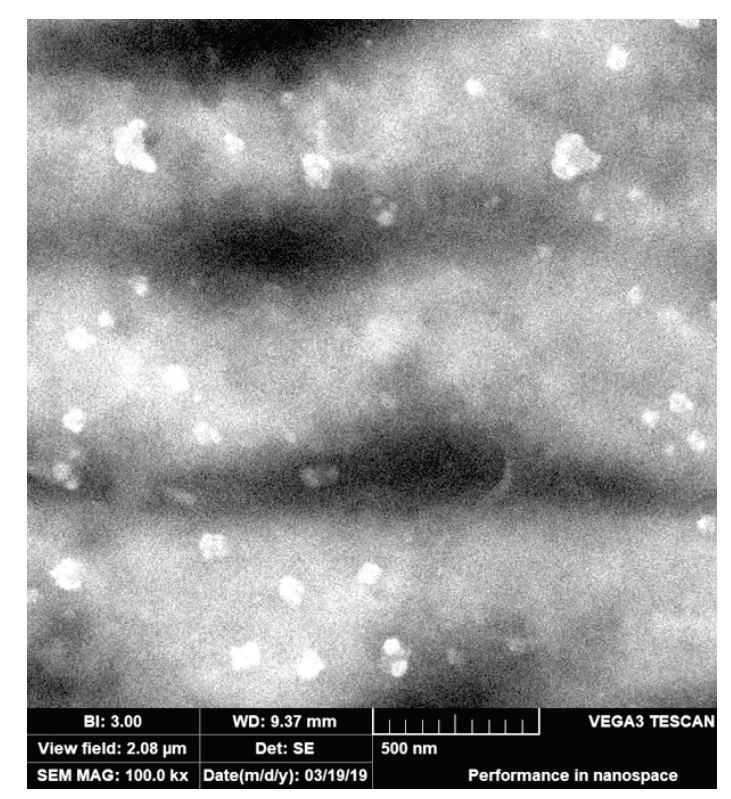

Fig. 1. SEM image of the Ag surface treated with femtosecond laser with the wavelength of $800 \mathrm{~nm}$ and the pulse irradiation energy density of $0.14 \mathrm{~J} / \mathrm{cm}^{2}$, the efficient number of laser pulses $N=850$ at the repetition rate of $1 \mathrm{kHz}$. 




Fig. 2. SEM image of the Au surface treated with femtosecond laser with the wavelength of $800 \mathrm{~nm}$ and the pulse irradiation energy density of $0.1 \mathrm{~J} / \mathrm{cm}^{2}$, the efficient number of laser pulses $N=40$ at the repetition rate of $1 \mathrm{kHz}$.

and refractory metal - tungsten are presented.

Under the mentioned laser processing parameters LIPSS is the most



Fig. 3. AFM image of $\mathrm{Cu}$ surface treated with femtosecond laser with the wavelength of $800 \mathrm{~nm}$ and the pulse irradiation energy density of $0.48 \mathrm{~J} / \mathrm{cm}^{2}$, the efficient number of laser pulses $N=135$ at the repetition rate of $1 \mathrm{kHz}$. 




Fig. 4. SEM image of the $\mathrm{W}$ surface treated with femtosecond laser with the wavelength of $800 \mathrm{~nm}$ and the pulse irradiation energy density of $0.29 \mathrm{~J} / \mathrm{cm}^{2}$, the efficient number of laser pulses $N=1200$ at the repetition rate of $1 \mathrm{kHz}$, laser scanning velocity of $0.5 \mathrm{~mm} / \mathrm{s}$.

prominent feature for almost all metal surfaces except gold surface, where the LIPSS is in the begging of its self-assembling. For gold surface the observed quasi-regular structure could also be explained by the influence of some hydrodynamic instabilities in the melted substance [14].

Furthermore, all the images demonstrate the presence of the features of nanoscale dimensions on the laser-treated surfaces: for silver surface the average size of nanofeatures is from $25 \mathrm{~nm}$ up to $80 \mathrm{~nm}$, for gold surface-from $60 \mathrm{~nm}$ up to $200 \mathrm{~nm}$, for copper-from $50 \mathrm{~nm}$ up to $250 \mathrm{~nm}$, for tungsten surface-from $30 \mathrm{~nm}$ up to $110 \mathrm{~nm}$.

Hereby, in the laser regime with the fluence around or slightly exceeding the ablation threshold the nanoparticles of rather small sizes are provided.

Figure 5 presents AFM images that indicate the transformation of surface of aluminium alloy with $20 \%$ silicon ( $\mathrm{Al}-\mathrm{Si}$ alloy) under the femtosecond laser treatment with different scanning velocities and efficient numbers of laser pulses. On the surface of the Al-Si alloy sample the structures that resemble granules have been formed under ultrashort laser irradiation. Moreover quasi-grating structure is observed on the surface of the granules. The orientation of the formed ripples is in a direction perpendicular to the incident laser beam polarization. The period of LIPSS is around $500 \mathrm{~nm}$. One can observe the evolution of quasi-granular structure with an increase of scanning veloci- 
ty and slight reduce of number of laser pulses. At greater velocity the dimensions of the granules reduce and average granular filling factor increases (see Fig. 5, c). Thus under the control of scanning velocity, power density and number of laser pulses the specific dimensional parameters of nanoscale formations on the surface could be obtained.

Earlier we demonstrated an efficient enhancement of Raman signal for the Ag surfaces treated under the femtosecond laser pulse irradiation in comparison with the non-treated surface [15]. It has been obtained the maximal enhancement factor of 20 for some vibration modes of Rhodamine 6G (Rh6G) dye adsorbed on the Ag quasi-periodic surface structures formed under pulse irradiation energy density of 0.53 $\mathrm{J} / \mathrm{cm}^{2}$ and efficient number of pulses of 135. At mentioned research Ag sample was polished before the procedure of laser treatment. At present study, we achieve SERS enhancement for Methylene Blue (MB) dye $\mathrm{C}_{16} \mathrm{H}_{18} \mathrm{ClN}_{3} \mathrm{~S}$ adsorbed on the LIPSS $\mathrm{Ag}$ structures which was not even polished before laser processing. MB dye is characterised by an emission centred around $690 \mathrm{~nm}$, with a fluorescence quantum yield of
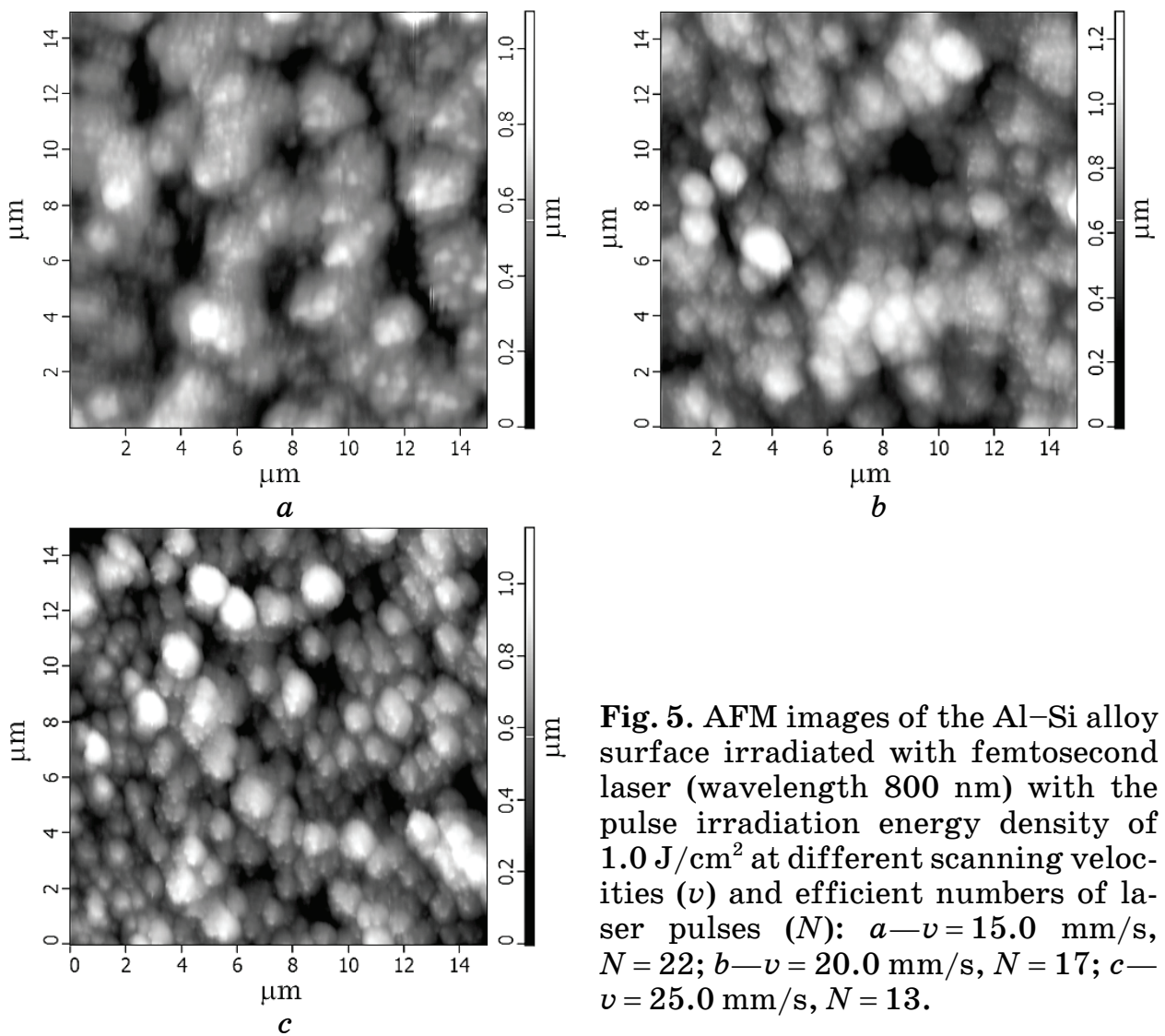

Fig. 5. AFM images of the Al-Si alloy surface irradiated with femtosecond laser (wavelength $800 \mathrm{~nm}$ ) with the pulse irradiation energy density of $1.0 \mathrm{~J} / \mathrm{cm}^{2}$ at different scanning velocities $(v)$ and efficient numbers of laser pulses $(N): a-v=15.0 \mathrm{~mm} / \mathrm{s}$, $N=22 ; b-v=20.0 \mathrm{~mm} / \mathrm{s}, N=17 ; c-$ $v=25.0 \mathrm{~mm} / \mathrm{s}, N=13$. 
0.52 [16]. We used aqueous solution of $\mathrm{MB}$ dye in concentration of around $2 \cdot 10^{-5} \mathrm{M}$. The morphology of the Ag sample demonstrates the quasi-periodic structure with the period of $770 \mathrm{~nm}$ and rather high height difference (see Fig. 6).

The features are of the size of around 100-200 $\mathrm{nm}$. Such kind of sample has been chosen to demonstrate that the ultrashort laser treatment can develop the formation of surface features with dimensions that provide the local plasmonic fields. Thus, Raman scattering of the embedded MB molecules is enhanced due to the localized electromagnetic field caused by the plasmonic resonances in the metal. The best results are obtained when the frequency of the incident and scattered light falls in the plasmon resonance.

The Raman spectra of MB dye adsorbed on laser-induced Ag structures demonstrate slight enhancement of the intensities of some characteristic vibrational bands of MB dye. As an example of such enhancement, at Fig. 7 the fragments of Raman spectra of MB dye deposited on original and laser-treated Ag surface are presented. Thus Raman spectrum of MB dye on one of the treated surfaces labeled by '2' reveals some prominent well-assigned vibrational bands of MB dye [17, 18], namely different bending deformation modes at 698,862 , and $1125 \mathrm{~cm}^{-1}$, the band around $1250 \mathrm{~cm}^{-1}$ assigned to the deformation ring vibration mode. Some band shifts have been observed in Raman spectra of the embedded MB molecules on LIPSS. These shifts may provide the evidence of the chemisorption of methylene blue molecules that is resulted in an enhancement of the chemical effects responsible for this shifts [19].



Fig. 6. AFM image of Ag surface treated with femtosecond laser with the wavelength of $800 \mathrm{~nm}$ and the pulse irradiation energy density of $0.34 \mathrm{~J} / \mathrm{cm}^{2}$, the efficient number of laser pulses $N=68$ at the repetition rate of $1 \mathrm{kHz}$. 


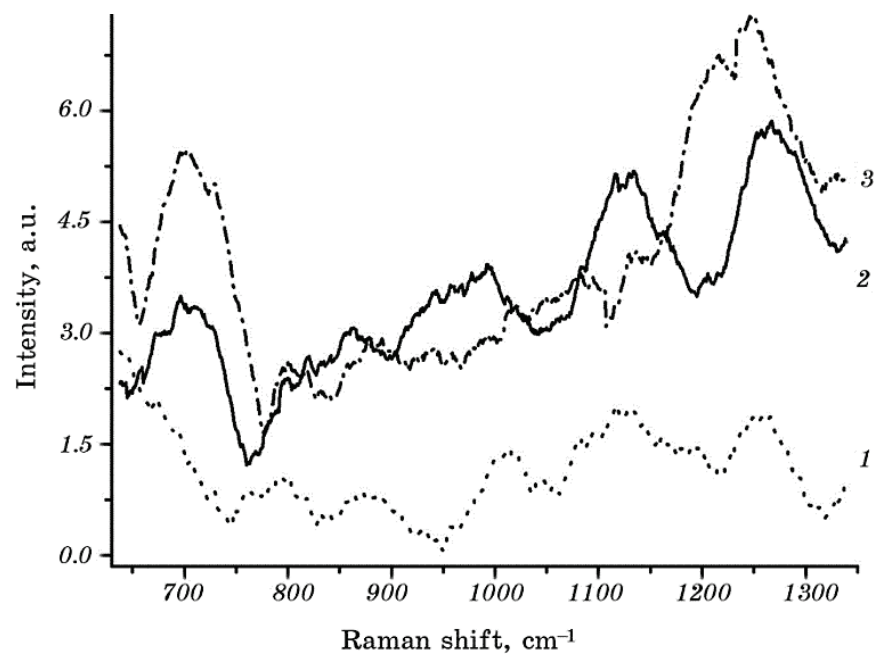

Fig. 7. Raman spectra of MB dye adsorbed on untreated Ag surface (1) and laser-structured Ag surface formed at different levels of the laser pulse irradiation energy density $(2,3)$. Excitation wavelength $-476.5 \mathrm{~nm}$.

\section{CONCLUSION}

Laser processing of noble metals (silver, gold, copper), refractory metal (tungsten) and metal-semiconductor alloy (Al-Si alloy) with ultrashort laser pulses of a Ti:Sapphire femtosecond laser has been carried out in air. An analysis of the morphology of the laser-treated surfaces demonstrates the laser-induced periodic surface structures (LIPSS) with different periods, nanoscale features (nanoparticles, tips), and nanoholes. Conditions of formation of different kinds of surface structures are discussed and summarized. The average sizes of nanoscale features formed under ultrashort laser processing on the surface structures have been determined for silver, gold, copper and tungsten. The process of laser ablation generally determines an appearance of these nanofeatures. An application of laser-processed noble metals as SERS substrates has been demonstrated. Thus, it has been obtained an enhancement of Raman signal for some vibrations of Methylene Blue dye adsorbed on laser-induced Ag surface structures which was not even polished before laser processing.

\section{ACKNOWLEDGEMENT}

This contribution was created under the support of project No. 19BF051-04 financed by Ministry of Education and Science of 
Ukraine. Authors appreciate technical support of Femtosecond Laser Center for Collective Use of N.A.S. of Ukraine.

\section{REFERENCES}

1. A. Y. Vorobyev and C. Guo, Laser Photonics Rev., 7: 385 (2013).

2. I. Etsion, J. Tribol., 127, No. 1: 248 (2005).

3. B. N. Chichkov, C. Momma, S. Nolte, F. Von Alvensleben, and A. Tünnermann, Appl. Phys.A, 63: 109 (1996).

4. K. C. Phillips, H. H. Gandhi, E. Mazur, and S. K. Sundaram, Adv. Opt. Photon., 7, No. 4: 684 (2015).

5. H. W. Chang, Y. C. Tsai, C. W. Cheng, C. Y. Lin, Y. W. Lin, and T. M. Wu, J. Colloid Interface Sci., 360: 305 (2011).

6. J. Bonse, S. V. Kirner, S. Hohm, N. Epperlein, D. Spaltmann, A. Rosenfeld, and J. Kruger, Proc. SPIE, 10092: 100920N (2017).

7. A. Wang, L. Jiang, X. Li, Q. Xie, B. Li, Z. Wang, K. Du, and Y. Lu, J. Mater. Chem. B, 5: 777 (2017).

8. S. Hamad, G. Krishna Podagatlapalli, Md. Ahamad Mohiddon, and V. Rao Soma, Appl. Phys. Lett., 104: 263104 (2014).

9. E. G. Gamaly, A. V. Rode, B. Luther-Davies, and V. T. Tikhonchuk, Phys. Plasmas, 9: 949 (2002).

10. P. T. Mannion, J. Magee, E. Coyne, G. M. O’Connor, and T. J. Glynn, Appl. Surf. Sci., 233: 275 (2004).

11. S. I. Anisimov, B. L. Kapeliovich, and T. L. Perel'man, Sov. Phys. JETP, 39: 375 (1974).

12. S. Nolte, C. Momma, H. Jacobs, A. Tunnermann, B. N. Chichkov,

B. Wellegehausen, and H. Welling, J.Opt.Soc. Am. B, 14, No. 10: 2716 (1997).

13. G. D. Tsibidis, C. Fotakis, and E. Stratakis, Phys. Rev. B, 92: 041405(R) (2015).

14. E. L. Gurevich and S. V. Gurevich, Appl. Surf. Sci., 302: 118 (2014).

15. N. Berezovska, I. Dmitruk, S. Vovdenko, O. Yeshchenko, P. Teselko,

A. Dmytruk, and I. Blonskyi, Indian J. Phys., 93: 495 (2019).

16. A. Felgenträger, T. Maisch, D. Dobler, and A. Späth, BioMed Research International, 482167 (2013).

17. Gui-Na Xiao and S.-Q. Man, Chem. Phys. Lett., 447: 305 (2007).

18. S. H. A. Nicolai and J. C. Rubim, Langmuir, 19, No. 10: 4291 (2003).

19. Z. Li, S. C. Xu, C. Zhang, X. Y. Liu, S. S. Gao, L. T. Hu, J. Guo, Y. Ma, S. Z. Jiang, and H. P. Si, Scientific Reports, 6: 38539-1 (2016). 